\title{
Microorganisms and Culture and Sensitivity Pattern in Chronic Suppurative Otitis Media in a Tertiary Care Hospital
}

Krishna Sundar Shrestha, ${ }^{1}$ Surendra Kumar Madhup, ${ }^{2}$ Bikash Lal Shrestha, ${ }^{1}$ Monika Pokharel, ${ }^{1}$ Ashish Dhakal' 'Department of ENT and HNS, Dhulikhel Hospital, Kathmandu University Hospital ${ }^{2}$ Department of Microbiology, Dhulikhel Hospital, Kathmandu University Hospital.

\section{ABSTRACT}

\section{Introduction}

CSOM is defined as persistent or intermittent infected discharge of more than three months duration through the perforated or non intact tympanic membrane caused by bacteria, fungi and virus resulting in inflammation of mucosal lining that often results in partial or total loss of tympanic membrane and ossicles. The aim of study was to study the current bacteriological profile responsible for the disease.

\section{Methods}

This descriptive cross sectional study was carried out at the department of Ear , Nose and Throat (ENT) and Head and Neck Surgery (HNS) in a tertiary care centre from January 2019 to December 2020. Ethical approval was taken from Institutional Review Committee (Reference number 52/2021). A convenient sampling method was used and data analysis was done in Microsoft Excel. Point estimate at $95 \%$ confidence interval was calculated along with frequency and proportion for binary data.

\section{Results}

There were a total of 324 patients included in the study. The age range was from five to sixty-eight years. Most patients were of the age group below 10 years. There were a total of 178 males and 146 females. The most common organism isolated were Staphylococcus aureus 145 (44.8\%) and Psedomonas aeruginosa $86(26.6 \%)$.

\section{Conclusions}

Staphylococcus aureus and Pseudomonas aeruginosa were the most common organisms responsible for chronic suppurative otitis media in our study.

Keywords: chronic suppurative otitis media; Staphyllococcus aureus.

Correspondence: Dr. Krishna Sundar Shrestha, Department of ENT and HNS, Dhulikhel Hospital, Kathmandu University Hospital. Email: krishnasundar082@yahoo.com, Phone: +977-9841097964 


\section{INTRODUCTION}

The diagnosis of chronic otitis media (COM) implies a permanent abnormality of pars tensa or flaccida, most likely as a result of earlier otitis media, negative middle ear pressure or otitis media with effusion. ${ }^{1}$ Earlier the term Chronic Suppurative Otitis Media (CSOM) was used which is defined as chronic inflammation of middle ear and mastoid cavity that may present with recurrent ear discharges or otorrhoea through a tympanic membrane perforation. $^{2}$

Although it is a global disease, its incidence remains higher in resource poorer countries. ${ }^{3-6}$ The disease is common in younger age group of lower socioeconomic class. The most common organisms associated with CSOM are Staphyllococcus aureus, and Pseudomonas. Other include Proteus, E coli, Klebsiella, Enterobacter, non fermenting gram negative bacteria and B hemolytic streptococcus. ${ }^{7}$

CSOM and various complications associated with the disease such as irreversible local destruction of middle ear structures, facial palsy, serious intracranial and extracranial complications are seen by otologists. Early microbiological diagnosis ensures prompt and effective treatment to avoid such complications.

Knowledge of the prevailing flora and their susceptibility to antimicrobials will guide the clinician as to prescribing an empirical regimen so that a better and more specific management can be provided to the patients. ${ }^{8}$

The objective of this study was to examine the current bacteriological profile responsible for the disease.

\section{METHODS}

A hospital based descriptive and cross sectional retrospective study was conducted in the department of ENT and HNS at Kathmandu University Hospital, Dhulikhel Hospital during the period of 2 years from January 2019 to December 2020. Ethical clearance was taken from institutional review committee of KU School of Medical Sciences. The sample size was calculated as follows:

$$
\begin{aligned}
\mathrm{n} & =\mathrm{Z}^{2 *} \mathrm{p} *(1-\mathrm{p}) / \mathrm{e}^{2} \\
& =(1.96)^{2 *} 0.5 *(1-0.5) /(0.09)^{2} \\
& =119
\end{aligned}
$$

where

$$
\begin{aligned}
& \mathrm{n}=\text { minimum required sample size } \\
& \begin{aligned}
\mathrm{Z}= & 1.96 \text { at } 95 \% \text { Confidence Interval } \\
\mathrm{p}= & \text { prevalence, } 50 \% \text { for maximum } \\
& \text { sample size } \\
\mathrm{q}= & 1-\mathrm{p} \\
\mathrm{e}= & \text { margin of error }, 9 \%
\end{aligned}
\end{aligned}
$$

The sample size was calculated to be 119 . Adding $10 \%$ as a non response rate, the minimum required sample size was 131 . We took data from 324 patients. Convenience sampling method was used.

Patients presenting in the ENT OPD with history of ear discharge were well explained about the procedure, its risk and benefits. Well informed consent was taken. The ear discharges were collected using sterile swab sticks which were properly labelled for each patient. The swab were taken to Microbiology laboratory for analysis. The swabs were plated on MacConkey agar, blood agar and chocolate agar and incubated aerobically at $37^{\circ} \mathrm{C}$ for 24 hours. The organisms were identified according to standard microbiological procedures. ${ }^{9}$ 


\section{RESULTS}

Table 1. Age distribution of patients

\begin{tabular}{|l|l|}
\hline Age in years & Number (Percentage) \\
\hline$<10$ & $118(36.4 \%)$ \\
\hline $11-20$ & $78(24 \%)$ \\
\hline $21-30$ & $47(14.5 \%)$ \\
\hline $31-40$ & $15(4.6 \%)$ \\
\hline $41-50$ & $28(8.7 \%)$ \\
\hline $51-60$ & $32(9.9 \%)$ \\
\hline $61-70$ & $6(1.9 \%)$ \\
\hline
\end{tabular}

Table 2. Sex distribution of patients

\begin{tabular}{|l|l|l|}
\hline Sex & Number & Percentage \\
\hline Male & 178 & 54.9 \\
\hline Female & 146 & 45.1 \\
\hline
\end{tabular}

Bacteriological profile in CSOM

\begin{tabular}{|c|c|c|c|}
\hline $\begin{array}{l}\text { Type of } \\
\text { bacteria }\end{array}$ & Organism & $\begin{array}{c}\text { Number of } \\
\text { isolates }\end{array}$ & Percentage \\
\hline \multirow{3}{*}{$\begin{array}{l}\text { Gram } \\
\text { positive }\end{array}$} & $\begin{array}{l}\text { Staphylococcus } \\
\text { aureus }\end{array}$ & 145 & 44.8 \\
\hline & $\begin{array}{l}\text { Streptococcus } \\
\text { pnemonia }\end{array}$ & 28 & 8.6 \\
\hline & Enterococcus & 2 & 0.6 \\
\hline \multirow{5}{*}{$\begin{array}{l}\text { Gram } \\
\text { negative }\end{array}$} & $\begin{array}{l}\text { Pseudomonas } \\
\text { aeruginosa }\end{array}$ & 86 & 26.6 \\
\hline & $\begin{array}{l}\text { Klebsiella } \\
\text { pnemonia }\end{array}$ & 32 & 9.9 \\
\hline & Escherichia coli & 16 & 5 \\
\hline & Proteus vulgaris & 10 & 3 \\
\hline & Enterobacter & 5 & 1.5 \\
\hline
\end{tabular}

\section{DISCUSSION}

CSOM is one of the most common ear diseases, which the otolaryngologists encounter in day to day clinical practice. It is a chronic inflammation of the mucoperiosteum of the middle ear cleft which leads to abundant discharge from the ear and hearing impairment that may have a serious long term effect on the language, auditory and cognitive development and on educational progress ${ }^{10}$
In our study CSOM was most commonly seen in the age group of below 10 years (36.4\%) and $11-20$ years $(24 \%)$. This finding was found to be similar in the study done by Shrestha et $\mathrm{al}^{11}$, Jha et $\mathrm{al}^{12}$, Vaidya et $\mathrm{al}^{13}$, Mansoor et $\mathrm{al}^{14}$, Wariso et $\mathrm{al}^{15}$ and Poorey et al. ${ }^{16}$ High prevalence in children and young adults may be attributed to the fact that they have lower immunity and also due to anatomical factors like shorter, wider and relatively horizontal Eustachian tube. But our finding was different from the study done by Loy et $\mathrm{al}^{17}$ in which the disease was prevalent in the age group 31-40 years.

In our study males were more commonly affected than females. This finding was similar to the study done by Vaidya et $\mathrm{al}^{13}$, Kumar et $\mathrm{al}^{18}$, Lodhi et $\mathrm{al}^{19}$, Yousuf et $\mathrm{al}^{20}$ and Ahmad et al. ${ }^{21}$ But this finding was different in the study done by Shrestha et $\mathrm{al}^{11}$, Mansoor et $\mathrm{al}^{14}$ and Loy et al. ${ }^{17}$

In our study Staphyllococcus aureus was found to be the most common organism (44.8\%), followed by Pseudomonas aeruginosa (26.6\%) and Klebsiella pneumonia (9.9\%). This finding was found to be similar in the study done by Shrestha et $\mathrm{al}^{11}$ where Staphylococcus aureus was found to be (32.2\%), Vaidya et $\mathrm{al}^{13}(54.54 \%)$. Similar finding was found in the study done by Loy et $\mathrm{al}^{17}$, Taj et $\mathrm{al}^{22}$ and Ahmad et al. ${ }^{23}$ The reason behind the Staphylococcus aureus being the most commonly involved organisms may be because of the geographical variation, opportunistic infection as it is the normal flora of nasal cavity and skin.

But in many other studies, Psedomonas aeruginosa was found to be the most common organism involved, like the study done by Mansoor et $\mathrm{al}^{13}$, Ahmad et $\mathrm{al}^{21}$, Iqbal et $\mathrm{al}^{24}$, Sharma et $\mathrm{al}^{25}$ and Yeo et $\mathrm{al}^{26}$.

\section{CONCLUSIONS}

Staphylococcus aureus and Pseudomonas aeruginosa were the most common organisms responsible for chronic suppurative otitis media 


\section{REFERENCES}

1. Browning GG. Chapter 3.Aetiopathology of inflammatory conditions of external and middle ear. In: Kerr AG (ed.) ScottBrown's Otolaryngology, $6^{\text {th }}$ edn. Vol 3. London: Arnold, 1997.

2. World Health Organization. Chronis suppurative otitis media: Burden of illness and management options. World Health Organisation. Geneva.2004

3. Monasta L, Ronfani L, Marchetti F, Montioco M, Vecchi Brumatti L, Bavcar A, et al. Burden of disease caused by otitis media: Systematic review and global estimates. PLoS One 2012;7:e36226

4. Shaheen MM, Raquib A, Ahmad SM. Prevalence and associated sociodemographic factors of chronic suppurative otitis media among rural primary school children of Bangladesh. Int J Paediatr Otorhinolaryngol 2012;76:1201-4

5. Ologe FE, Nwawolo CC. Chronic suppurative otitis media in schhol pupils in Nigeria. East Alf Med J 2003;80:130-4

6. Alho OP, Jokinen K, Laitakari K, Palokangas J. Chronis suppurative otitis media and cholesteatoma. Vanishing diseases among western populations? Clin Otolaryngol Allied Sci 1997; 22: 35861

7. Varshney S, Gupta P. Bacteriological study of chronic suppurative otitis media, Indian J Otol 1999;5:87-91

8. Srivastava A, Singh RK, Varshney $S$, Gupta P, Bist SS, Bhagat S and Gupta N.Microbiological evaluation of an active tubotympanic type of chronic suppurative otitis media. Nepalese Journal of ENT Head and Neck Surgery2010;1(2):14-6

9. Duiguild JP, Collee JG,Fraser AG, Laboratory strategyin the diagnosis of infective syndromes. In Collee JG, Marmion BP, FraserAG, Simmons A, Mackie and Mcartney practical medical microbiology. 14 th edition, London. 1996

10. Healy GB, Rosbe KW. Otitis media and middleeareffusions.InSnow, BellengerJJ, editors. Bellenger's Otorhinolaryngology Head Neck Surgery (16 ${ }^{\text {th }}$ ed). BC Decker Inc;2003:249-60

11. Shrestha BL, Amatya RCM, Shrestha I and Ghosh I. Microbiological profile of chronic suppurative otitis media. Nepalese Journal ENT Head and Neck Surgery 2011;2(2):6-7

12. Jha AK, Singh JB and Dutta D. Microorganisms presenting in discharging otitis media in a group of patients in Kathmandu. Nepal Med Coll J 2007;9(3)

13. Vaidya K, Madhup SK, Shrestha BL, Gautam A, Tuladhar NR. Bacteriological and Mycological profile of Chronic Suppurative Otitis Media among patients visiting Dhulikhel Hospital. ACCLM 2015;1(1):37-41

14. Manssor T, Musani MA, Khalid G, Kamal M. Psedomonas aeruginosa in chronic suppurative otitis media: sensitivity spectrum against various antibiotics in Karachi. J Ayub Med Coll Abbottabad 2009;21(2):120-23

15. Wariso BA, Ibe SN. Bacteriology of 
chronic discharging ears in Port Harcourt, Nigeria. West Afr J Med 2006;25:219-22

16. Poorey VK and Lyer A. Study of bacterial flora in CSOM and its clinical significance. Indian J Otolaryngol Head Neck Surg 2002;54:91-5

17. Loy AHC, Tan AL, Lu PKS. Microbiology of chronic suppurative otitis media in Singapore, Singapore Med J 2002;43:296-9

18. Kumar $\mathrm{H}$ and Seth S. Bacterial and fungal study of 100 cases of chronic suppurative otitis media. J Clin Diagn Res 2011;5(6):1224-7

19. Lodhi M, Munir T, Aziz K and Lodhi H. Chronic suppurative otitis media; Empirical quinolones in children. Professional Med J 2010;17(3):420-24

20. Yousuf M, Majumdar K A, Kamal A, Shumon AM and Zaman Y. Clinical study on chronic suppurative otitis media with cholesteatoma. Bangladesh J Otolatyngol 2011;17(1):42-7

21. Ahmed A, Usman J, Hashim R. Isolates from chronic suppurative otitis media and their antimicrobial sensitivity. Pak Armed Forces Med J 1999;49:82-5

22. Taj Y, Essa F, Kazmi SU. Pathological analysis of 596 cases of chronic suppurative otitis media in Karanchi. J CollPhysicians Surg Pak.2000;10;33-5

23. Ahmed B, Hydri AS, Afridi AAK, Ejaz A, Farooq S, Zaidi SK. Microbiology of ear discharge in Quetta. J Coll Physicians Surg Pak 2005;15:583-4

24. Iqbal SM, Udaipurwala IH, Hasan A, Shafiq M, Mughal S. Chronic suppurative otitis media: Disease pattern and drug sensitivity. J Surg Pak 2006;11:17-9

25. Sharma S, Rehan HS, Goyal A, Jha AK, Upadhyaya $S$ and Mishra SC. Bacteriological profile in chronic suppurative otitis media in Eastern Nepal. Trop 2004;34:102-4

26. Yeo SG, Park DC, Hong SM, Cha CI, Kim MG. Bacteriology of chronic suppurative otitis media- a multicentre study. Acta Otolaryngol 2007;127:1062-67

Citation: Shrestha S, Madhup S, Shrestha B, Pokharel M, Dhakal A. Study of Microorganisms and Culture and Sensitivity Pattern in Chronic Suppurative Otitis Media in a Tertiary Care Hospital. JCMS Nepal. 2021; 17(3); $252-56$. 